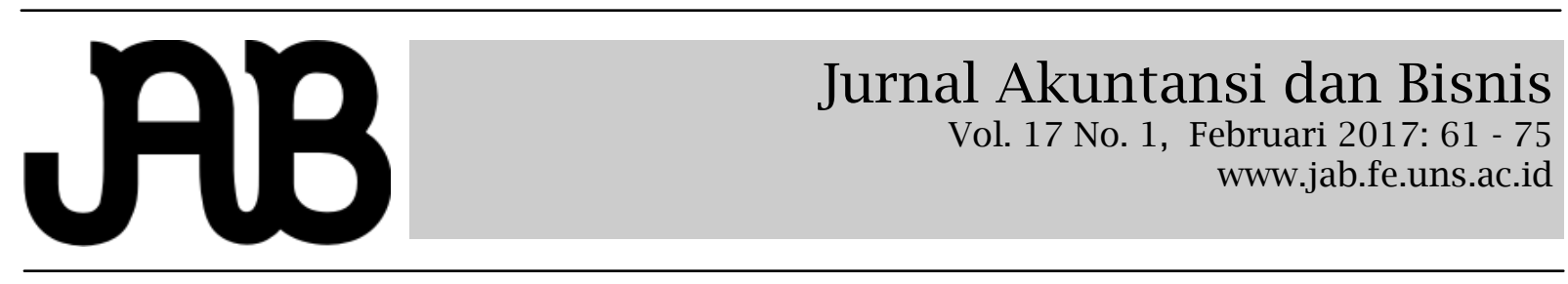

\title{
ANALISIS PENGARUH PERBEDAAN LABA AKUNTANSI DENGAN LABA FISKAL DAN KOMPONEN LABA TERHADAP PERSISTENSI LABA
}

\author{
RATRI ANNISA \\ LULUS KURNIASIH (loez_80@yahoo.com)
}

Program Studi Akuntansi, Fakultas Ekonomi dan Bisnis, Universitas Sebelas Maret

A B S T R A C T

The objective of this research is to examine the book-tax differences and the current earnings components. The book-tax differences are represented through large positive book-tax differences and large negative book-tax differences. The earnings components under this research are the cash flows and accruals. The cash flows were measured from operational cash flows, while the accruals were measured from the differences of pre-tax book income which was deducted by the operational cash flows. The Earning presistence is represented through pre-tax book income. This research employed multiple linear regression as its methodology. This research was conducted in all manufactured companies registered in Indonesia Stock Exchange during 2011-2013. This research uses purposive sampling method. The result shows that the large positive tax-book differences and the operational cash flows have a significant impact towards the earning presistence. Moreover, the accruals also have a positive significant impact towards the earning presistence. In the other side, the large negative book-tax differences do not have a significant impact towards the earning presistence.

Keywords : Book-tax Differences, Operational Cash Flows, Accruals, Earning Presistence.

Tujuan dari penelitian ini adalah untuk menguji perbedaan laba akuntansi dengan laba fiskal dan komponen laba saat ini. Perbedaan laba akuntansi dan laba fiskal diproksikan dengan menggunakan perbedaan laba akuntansi dan laba fiskal bernilai positif serta perbedaan laba akuntansi dan laba fiskal bernilai negatif. Komponen laba saat ini yang diteliti adalah arus kas dan akrual. Arus kas diukur dari arus kas operasi, sedangkan akrual diukur dari selisih laba akuntansi sebelum pajak dikurangi arus kas operasi. Persistensi laba diproksikan dengan laba akuntansi sebelum pajak. Penelitian ini menggunakan metode analisis regresi berganda. Penelitian ini dilakukan pada seluruh perusahaan manufaktur yang terdaftar di Bursa Efek Indonesia pada tahun 2011-2013. Metode pengambilan sampel yang digunakan dalam penelitian ini adalah metode purposive sampling. Hasil analisis menunjukkan bahwa perbedaan laba akuntansi dengan laba fiskal bernilai positif dan arus kas operasi berpengaruh signifikan terhadap persistensi laba. Akrual berpengaruh positif dan signifikan terhadap persistensi laba. Sedangkan untuk perbedaan laba akuntansi dengan laba fiskal bernilai negatif tidak berpengaruh signifikan terhadap persistensi laba.

Kata Kunci : Perbedaan Laba Akuntansi dengan Laba Fiskal, Arus Kas Operasi, Akrual, Persistensi Laba.

\section{PENDAHULUAN}

Pelaporan keuangan merupakan cara perusahaan menginformasikan kondisi keuangan dari hasil kegiatan operasi selama periode tertentu kepada berbagai pihak yang berkepentingan, sepeti investor, kreditor, pemerintah, dan pembuat kebijakan. Statement of Financial Accounting Concepts (SFAC) No. 1 dalam Dechow, Ge dan Schrand (2010) menyatakan bahwa pelaporan keuangan diharapkan dapat memberikan informasi tentang kinerja keuangan suatu perusahaan selama periode tertentu. Adapun tujuan dari laporan keuangan, dalam Pernyataan Standar Akuntansi Indonesia (PSAK) No. 1 (2009), adalah memberikan informasi mengenai posisi keuangan, kinerja keuangan, dan arus kas perusahaan yang bermanfaat bagi sebagian 
besar kalangan pengguna laporan dalam pembuatan keputusan ekonomi. Dengan demikian informasi yang terkandung dalam laporan keuangan merupakan dasar pengambilan keputusan oleh pihak-pihak yang berkepentingan. Salah satu informasi utama dalam laporan keuangan adalah informasi mengenai laba.

Laba merupakan pusat pertimbangan para pengguna laporan keuangan dalam pengambilan keputusan, seperti pengukur kinerja manajemen, pemberian kompensasi kepada manajer, dan pembagian deviden kepada pemegang saham. Pengambilan keputusan yang dilakukan oleh pengguna laporan keuangan memerlukan informasi yang relevan. Oleh karena itu, laba yang berkualitas diperlukan dalam pengambilan keputusan ekonomi. Laba yang berkualitas adalah laba yang dapat mencerminkan kelanjutan laba (sustainable earnings) di masa depan dan kinerja keuangan perusahaan yang sesungguhnya (Wijayanti, 2006). Laba yang berkualitas dapat ditinjau dari tingkat persistensi laba.

Persistensi laba adalah salah satu indikator untuk mengetahui kualitas laba perusahaan. Menurut Fanani (2010), persistensi laba menjadi pusat perhatian bagi para pengguna laporan keuangan, khususnya bagi mereka yang mengharapkan persistensi laba yang tinggi. Jika laba yang diperoleh pada tahun berjalan dapat menjadi indikator yang baik untuk laba di masa depan, maka laba tersebut dikatakan laba yang persisten. Laba yang tidak terlalu berfluktuatif adalah ciri-ciri dari laba yang persistensi dan kualitas laba yang dilaporkan oleh perusahaan adalah baik (Suwandika \& Astika, 2013).

Selain menjadi dasar pengambilan keputusan, laba juga sebagai kriteria untuk memenuhi asumsi kelangsungan hidup. Hal ini, memotivasi manajemen untuk melakukan perekayasaan pada laba yang dilaporkan agar tetap dalam kondisi yang tinggi persistensinya. Selain itu, akibat adanya kesenjangan informasi antara pengguna laporan keuangan yang memiliki keterbatasan informasi dengan manajemen yang sangat mengetahui kondisi perusahaan yang sebenarnya, karena sebagai pihak yang membuat laporan keuangan tersebut. Fanani (2010) mengungkapkan bahwa laba dalam laporan keuangan sering direkayasa oleh manajemen untuk menarik calon investor.

Para peneliti di bidang perpajakan sangat tertarik dengan perbedaan laba akuntansi dan laba fiskal (book-tax difference), banyak penelitian yang membahas tema tersebut. Mills dan Newberry (2001) dalam Anggarsari (2009) membuktikan bahwa perbedaan laba akuntansi dan laba fiskal berhubungan dengan insentif pelaporan keuangan, seperti financial distress dan pemberian bonus. Ayers, Laplante dan McGuire (2008), menguji secara empiris keterkaitan perbedaan laba akuntansi dan laba fiskal dengan perubahan peringkat kredit perusahaan. Menurut peneliti, perbedaan laba akuntansi dan laba fiskal sebagai sinyal kualitas laba bagi kreditor. Hasilnya menunjukkan signifikan negatif hubungan antara perbedaan laba akuntansi dan laba fiskal dengan perubahan peringkat kredit. Kraft (2015) membuktikan bahwa perbedaan laba akuntansi dan laba fiskal berguna sebagai discretionary accruals dalam mendeteksi manajemen laba.

Tang dan Firth (2011) mendapatkan bukti empiris bahwa perbedaan abnormal antara laba akuntansi dan laba fiskal berguna sebagai proksi manajemen laba dan manajemen pajak, perusahaanperusahaan terbuka di Cina sebagai sampel penelitian tersebut.

Huang dan Wang (2013) meneliti hubungan antara perbedaan laba akuntansi dan laba fiskal dengan kualitas laba pada industri perbankan di Taiwan. Hasil penelitian menunjukkan bahwa bank komersial yang memiliki beda temporer besar antara laba akuntansi dan laba fiskal yang bernilai positif atau bernilai negatif menunjukkan discretionary loan loss provisions yang lebih besar dibandingkan dengan bank komersial yang memiliki beda kecil di perbedaan laba akuntansi dan laba fiskal. Artinya, kualitas laba bank komersial tersebut lebih rendah dibandingkan dengan bank komersial yang memiliki beda kecil diperbedaan laba akuntansi dan laba fiskal. 
Jackson (2009) menguji hubungan antara perbedaan laba akuntansi dan laba fiskal dengan pertumbuhan laba. Perbedaan laba akuntansi dan laba fiskal dibagi menjadi dua berdasarkan komponennya, yaitu perbedaan temporer dan perbedaan permanen. Hasil penelitian menunjukkan bahwa perbedaan permanen hanya berhubungan dengan perubahan beban pajak, sedangkan perbedaan temporer berhubungan dengan laba akuntansi sebelum pajak. Serupa dengan Persada dan Martani (2010), beda temporer dan beda permanen terbukti signifikan berhubungan dengan persistensi laba.

Perbedaan laba akuntansi dan laba fiskal adalah perbedaan antara jumlah laba pada laporan keuangan komersial dan jumlah laba pada laporan keuangan fiskal. Laba akuntansi dihitung berdasarkan peraturan akuntansi, sedangkan laba fiskal dihitung berdasarkan peraturan perpajakan. Ketidaksamaan perhitungan laba yang terjadi setiap tahunnya akan mempengaruhi pertumbuhan laba suatu periode perusahaan dikarenakan perusahaan harus menyesuaikan kembali perhitungan laba akuntansi dengan peraturan perpajakan (Dewi \& Putri, 2015). Hal ini disebabkan adanya perbedaan tujuan antara peraturan akuntansi dengan peraturan perpajakan.

Perbedaan laba akuntansi dan laba fiskal dapat memberikan informasi mengenai kualitas laba. Blaylock, Shevlin dan Wilson (2012) mengungkapkan bahwa large positive book-tax difference menyediakan informasi yang bermanfaat dan luas mengenai persistensi laba melebihi informasi yang disediakan oleh akrual.

Serupa dengan hasil penelitian Hanlon (2003), Wijayanti (2006), dan Tang dan Firth (2012) menemukan bahwa perusahaan dengan perbedaan besar, baik perbedaan besar antara laba akuntansi dan laba fiskal yang bernilai positif maupun yang bernilai negatif (large positive atau large negative book-tax difference) menunjukkan persistensi yang lebih rendah dibandingkan dengan perusahaan yang perbedaan kecil antara laba akuntansi dan laba fiskal (small book-tax difference), yang disebabkan oleh peraturan, standar dan tindakan oportunistik, salah satunya manajemen laba. Blaylock et al. (2012) menyatakan bahwa perbedaan laba akuntansi dan laba fiskal dapat menunjukkan laba yang lebih persisten, jika perbedaan laba akuntansi dan laba fiskal timbul dari kegiatan perencanaan pajak. Hasil penelitian Wijayanti (2006) membuktikan bahwa perbedaan laba akuntansi dan laba fiskal yang memiliki komponen akrual lebih besar, menyebabkan laba kurang persisten.

Penelitian dibidang perkiraan laba (earning forecast) menyoroti betapa pentingnya menganilisis komponen akrual dan arus kas yang merupakan komponen laba saat ini. Kedua komponen tersebut memiliki karakteristik yang berbeda. Komponen akrual memiliki sifat transitori, karena dipengaruhi oleh peristiwa transitori. Oleh karena itu, komponen akrual lebih subyektif dibandingkan dengan komponen arus kas. Komponen arus kas mewakili sifat permanen, karena lebih obyektif dan nyata (Boubakri, 2012).

Menurut Sloan (1996) dalam Fanani (2010), komponen akrual dan arus kas yang terkandung pada laba saat ini menentukan persistensi laba. Laba yang memiliki sifat transitori menunjukkan persistensi laba yang lebih rendah dibandingkan dengan laba yang memiliki sifat permanen. Ahn dan Kwon (2010) menghasilkan bukti empiris bahwa komponen arus kas berkontribusi terhadap tingkat persistensi laba yang tinggi daripada komponen akrual.

Berdasarkan latar belakang masalah tersebut, penulis tertarik untuk meneliti bagaimana pengaruh perbedaan laba akuntansi dan laba fiskal dan komponen laba terhadap persistensi laba.

\section{TINJAUAN PUSTAKA DAN PENGEM- BANGAN HIPOTESIS \\ Persistensi Laba}

Laba didefinisikan sebagai hasil proses pendapatan dikurangi beban. Pendefinisian ini merupakan definisi secara struktural karena laba tidak dapat dipisahkan dari pengertian pendapatan dan biaya (Suwardjono, 2014). Informasi laba yang 
terkandung dalam laporan keuangan merupakan informasi yang sangat diminati oleh pengguna laporan keuangan. Karena pengguna laporan keuangan menggunakan informasi laporan keuangan sebagai dasar pengambilan keputusan, seperti keputusan investasi, pembuatan kontrak, penghargaan kinerja, dan sebagainya (Fanani, 2010).

Pengambilan keputusan yang dilakukan oleh pengguna laporan keuangan memerlukan informasi yang relevan. Oleh karena itu, laba yang berkualitas diperlukan dalam pengambilan keputusan ekonomi. Laba yang berkualitas adalah laba yang dapat mencerminkan kelanjutan laba (sustainable earnings) di masa depan dan kinerja keuangan perusahaan yang sesungguhnya (Wijayanti, 2006). Schipper dan Vincent (2003) dalam Anggarsari (2009) mengatakan bahwa laba yang berkualitas tinggi adalah laba yang mempunyai kemampuan tinggi dalam memprediksi laba di masa mendatang. Sedangkan Chandrarin (2001) dalam Wijayanti (2006) mengungkapkan laba akuntansi yang berkualitas adalah laba yang sedikit atau tidak mengandung gangguan persepsi (perceived noise), dan dapat mencerminkan kinerja perusahaan yang sebenarnya. Hayn (1995) dalam Wijayanti (2006) menjelaskan bahwa gangguan persepsian disebabkan oleh peristiwa transitori atau penerapan proses akrual dalam akuntansi. Peristiwa transitori adalah peristiwa yang terjadi pada waktu tertentu dan mempengaruhi pada periode waktu peristiwa terjadi.

Kualitas laba merupakan suatu ukuran untuk mencocokan apakah laba yang dihasilkan sama dengan apa yang sudah direncanakan sebelumnya (Paulus, 2012, dalam Razshinta, 2015). Menurut Bellovery et al. (2005) dalam Razshinta (2015), kualitas laba sebagai kemampuan dalam merefleksikan kebenaran laba perusahaan dan membantu memprediksi laba mendatang, dengan mempertimbangkan stabilitas dan persistensi laba.

Dechow et al. (2010) membagi alat ukur kualitas laba kedalam tiga kategori, diantaranya properties of earnings, investor responsiveness to earnings dan external indicator of earnings misstatements. Properties of earnings meliputi persistensi laba dan akrual, perataan laba (earnings smoothness), ketepatan waktu (asymmetric timeliness and timely loss recognition), dan target beating. Investor responsiveness to earnings meliputi earnings response coefficient (erc). External indicator of earnings misstatements meliputi accounting and auditing enforcement releases (AAERs), prosedur pengendalian internal dibawah peraturan Sarbanes Oxley Act, dan indikator kesalahan lainnya.

Persistensi laba merupakan salah satu alat ukur kualitas laba, seperti yang telah disebutkan sebelumnya. Jonas dan Blanchet (2000) dalam Suwandika dan Astika (2013) menyatakan persistensi laba sering digunakan sebagai kualitas laba karena merupakan komponen dari karakteristik kualitatif relevansi yaitu predictive value. Persistensi laba dipilih sebagai alat ukur kualitas laba oleh Bart dan Hutton (2001) dalam Fanani (2010) karena sangat relevan dalam perspektif kegunaan keputusan dan mencerminkan tujuan dari informasi akuntansi.

Penman (2001) dalam Fanani (2010) menyatakan bahwa persistensi laba adalah laba akuntansi yang diharapkan di masa mendatang (expected future earnings) yang tercermin pada laba tahun berjalan (current earnings). Fanani (2010) mengungkapkan bahwa pengertian persistensi laba dapat dipandang dalam dua sudut pandang. Pandangan pertama menyatakan bahwa persistensi laba berhubungan dengan kinerja keseluruhan perusahaan yang tergambarkan dalam laba perusahaan. Sedangkan pandangan kedua menyatakan bahwa persistensi laba berhubungan dengan kinerja saham perusahaan di pasar modal.

Wijayanti (2006) menyatakan bahwa laba yang persisten adalah laba akuntansi yang dapat mencerminkan keberlanjutan laba di masa depan yang ditentukan oleh komponen akrual dan aliran kas. Laba yang tidak terlalu berfluktuatif merupakan ciriciri dari laba yang persisten dan kualitas laba yang dilaporkan perusahaan adalah baik. Menururt Penman dan Zang (2002) laba dapat dikatakan berkualitas tinggi, 
ketika penghasilannya persisten dan berkelanjutan.

\section{Perbedaan Laba Akuntansi dan Laba Fiskal}

Perbedaan laba akuntansi dan laba fiskal, disebut juga book-tax differences atau book -tax gap, diartikan sebagai selisih antara laba komersil dan laba fiskal (Wiryandari \& Yulianti, 2009). Sedangkan, Martani, Fitriasari dan Yulianti (2010) mendefinisikannya sebagai perbedaan antara pendapatan akuntansi dan pendapatan pajak. Menurut Persada dan Martani (2010), book-tax gap adalah perbedaan laba yang dihasilkan berdasarkan akuntansi dan pajak disebabkan oleh peraturan perpajakan dan akuntansi yang memiliki tujuan berbeda. Serupa dengan penjelasan Plesko (2004) dalam Anggarsari (2009) bahwa perbedaan laba akuntansi dan laba fiskal merupakan perbedaan pelaporan laba yang disebabkan karena perbedaan konsep dan peraturan dalam masing-masing sistem pelaporan

Perbedaan ini timbul karena adanya perbedaan tujuan antara aturan akuntansi dengan aturan perpajakan. Aturan akuntansi bertujuan untuk menciptakan laporan keuangan yang relevan dan dapat diandalkan oleh pengguna laporan keuangan, seperti manajemen, investor, dan kreditor, untuk pengambilan keputusan. Sedangkan peraturan perpajakan bertujuan untuk pemungutan yang adil dan terjaganya pendapatan negara yang berasal dari pajak. Oleh karena itu, beban dan penghasilan yang diatur oleh peraturan perpajakan lebih ketat, sehingga laba akuntansi berbeda dengan laba fiskal (Persada \& Martani, 2010).

Laba yang dilaporkan pada laporan keuangan komersial disebut laba akuntansi. Laba Akuntansi adalah laba atau rugi bersih dalam suatu periode akuntansi sebelum dikurangi beban pajak laba (rugi) sebelum pajak (Waluyo, 2014). Laba yang dilaporkan pada laporan keuangan fiskal disebut laba fiskal. Laba Fiskal diperoleh dari hasil rekonsiliasi/koreksi fiskal terhadap laba sebelum pajak. Rekonsiliasi dilakukan untuk menyesuaikan antara pendapatan dengan beban yang diakui atau tidak diakui dan metode pengakuan serta pengukuran yang diperkenankan oleh peraturan perpajakan (Persada \& Martani, 2010).

Perbedaan antara laba akuntansi dan laba fiskal dapat dikelompokkan menjadi perbedaan tetap/permanen (permanent diffrences) dan perbedaan temporer (temporary differences), berdasarkan pengakuan pendapatan dan beban antara aturan akuntansi dan peraturan perpajakan (Suandy, 2011).

\section{Perbedaan tetap/permanen (permanent diffrences)}

Perbedaan tetap/permanen (permanent differences) adalah perbedaan yang timbul karena adanya perbedaan pengakuan pendapatan dan beban antara standar akuntansi dan peraturan perpajakan tanpa adanya koreksi fiskal dikemudian hari. Sehingga laba fiskal yang diperoleh akan berbeda jumlahnya dengan laba akuntansi. Perbedaan permanen positif apabila ada pendapatan akuntansi yang tidak diakui berdasarkan peraturan perpajakan dan pembebasan pajak, sedangkan perbedaan permanen negatif disebabkan adanya beban akuntansi yang tidak diakui oleh peraturan perpajakan (Suandy, 2011). Contoh, pemberian imbalan kepada karyawan dalam bentuk natura dan kenikmatan merupakan biaya yang tidak dapat dibebankan kepada laba akuntansi, dan tidak diakui sebagai pendapatan bagi Wajib Pajak yang menerimanya.

\section{Perbedaan temporer (temporary differences) \\ Perbedaan temporer (temporary} differences) adalah perbedaan yang sifatnya sementara karena adanya perbedaan waktu dan metode pengakuan pendapatan dan beban tertentu berdasarkan standar akuntansi dan peraturan perpajakan. Perbedaan temporer dibagi menjadi dua perbedaan, yaitu perbedaan waktu positif dan perbedaan waktu negatif. Perbedaan waktu positif terjadi apabila pengakuan beban untuk akuntansi lebih lambat dari pengakuan beban untuk pajak atau pengakuan penghasilan untuk tujuan pajak lebih lambat dari pengakuan penghasilan 
untuk tujuan akuntansi. Perbedaan waktu negatif terjadi jika ketentuan perpajakan mengakui beban lebih lambat dari pengakuan beban akuntansi komersial atau akuntansi mengakui penghasilan lebih lambat dari pengakuan penghasilan ketentuan pajak (Suandy, 2011). Oleh karena itu, perbedaan temporer dapat mengakibatkan pajak yang dibayarkan menjadi lebih kecil atau lebih besar dimasa mendatang, sehingga menimbulkan aset atau liabilitas pajak tangguhan (Persada \& Martani, 2010).

Serupa dengan penelitian-penelitian terdahulu (Hanlon (2003); Wijayanti (2006); Wiryandari dan Yulianti (2009); Blaylock et al. (2012); Suwandika dan Astika (2013)), penelitian ini hanya fokus pada perbedaan temporer. Karena perbedaan temporer menimbulkan jumlah pajak yang dapat ditambahkan (future taxable amount) atau dikurangkan (future deductible amount) dimasa depan, yang berhubungan dengan proses akrual sehingga dapat digunakan untuk penilaian kualitas laba masa depan. Sedangkan, perbedaan permanen hanya mempengaruhi periode terjadinya, tidak mengindikasikan kualitas laba yang berhubungan dengan proses akrual, dan tidak menimbulkan konsekuensi adanya penambahan atau pengurangan jumlah pajak masa depan (Wijayanti, 2006). Hasil penelitian Jackson (2009) menunjukkan bahwa perbedaan permanen hanya berkaitan dengan perubahan masa depan pada beban pajak, sedangkan perbedaan temporer berhubungan dengan perubahan pada laba sebelum pajak (pretax earning).

Hanlon (2005) dalam Supriyono (2013) menyatakan perbedaan laba akuntansi dan laba fiskal dapat dibagi menjadi tiga, yaitu large positive book-tax differences, large negative book-tax differences, dan small book-tax differences.

\section{Large positive book-tax differences}

Large positive book-tax differences merupakan selisih antara laba akuntansi dan laba fiskal, perbedaan besar yang bernilai positif ini karena laba akuntansi lebih besar dari laba fiskal (Supriyono, 2013). Large positive book-tax differences timbul apabila perbedaan temporer menyebabkan terjadinya koreksi fiskal negatif dalam laporan rekonsiliasi fiskal. Koreksi fiskal negatif adalah penyesuaian terhadap laporan komersial sehingga menurunkan penghasilan (laba) fiskal, disebabkan adanya penurunan atau penghapusan penghasilan karena penghasilan tersebut bukan merupakan Objek Pajak atau merupakan penghasilan yang dikenakan pajak final. Koreksi negatif juga disebabkan oleh kenaikan biaya yang dapat dikurangkan seperti selisih penggunaan metode penilaian persediaan, atau selisih penggunaan metode penyusutan aktiva tetap (Sumarsan, 2013).

Koreksi negatif akan menimbulkan beban pajak tangguhan (deferred tax expense) di laporan laba rugi dan liabilitas pajak tangguhan (deferred tax liabilities) di neraca (Supriyono, 2013). Beban pajak tangguhan adalah jumlah beban pajak tangguhan yang muncul akibat adanya pengakuan atas liabilitas pajak tangguhan. Liabilitas pajak tangguhan adalah jumlah pajak penghasilan terutang untuk periode mendatang sebagai akibat adanya perbedaan temporer kena pajak (Waluyo, 2014).

\section{Large negative book-tax differences}

Large negative book-tax differences merupakan selisih antara laba akuntansi dan laba fiskal, perbedaan besar yang bernilai negatif ini karena laba akuntansi lebih kecil dari laba fiskal (Supriyono, 2013). Large negative book-tax differences timbul apabila perbedaan temporer menyebabkan terjadinya koreksi fiskal positif dalam laporan rekonsiliasi fiskal. Koreksi fiskal positif adalah penyesuaian terhadap laporan komersial sehingga meningkatkan penghasilan (laba) fiskal, disebabkan oleh penurunan atau penghapusan beban karena beban tersebut bukan merupakan non-deductible expense atau beban yang tidak boleh mengurangi penghasilan fiskal. Koreksi positif juga dipengaruhi oleh kenaikan penghasilan yang belum diakui dalam laporan keuangan komersial (Sumarsan, 2013).

Koreksi positif akan menimbulkan manfaat pajak tangguhan (deferred tax benefits) di laporan laba rugi dan aset pajak 
tangguhan (deferred tax assets) di neraca (Supriyono, 2013). Manfaat (penghasilan) pajak tangguhan adalah jumlah keuntungan atau manfaat pajak tangguhan yang muncul akibat adanya pengakuan atas aset pajak tangguhan. Aset pajak tangguhan adalah jumlah pajak penghasilan yang terpulihkan (recovered) pada periode mendatang sebagai akibat perbedaan temporer yang boleh dikurangkan dan sisa kerugian yang dapat dikompensasikan (Waluyo, 2014).

\section{Small book-tax differences}

Small book-tax differences merupakan perbedaan laba akuntansi dan laba fiskal yang bernilai cukup kecil. Nilai perbedaan laba akuntansi dan laba fiskal yang semakin kecil menunjukkan kualitas laba yang semakin baik (Supriyono, 2013).

\section{Komponen Laba}

Menurut Penman (2001) dalam Fanani (2010), komponen laba saat ini, yang terdiri dari arus kas dan akrual, yang menentukan persistensi laba. Menurut Fanani (2010), nilai yang terkandung di dalam arus kas pada suatu periode mencerminkan nilai laba dalam metode kas. Dasar akrual yang tertuang di dalam standar akuntansi merupakan syarat dalam pencatatan transaksi, sehingga akrual menjadi komponen laba saat ini.

Hasil penelitian Bart et al. (1999) dalam Anggono dan Baridwan (2003) membuktikan bahwa arus kas dan akrual memberikan tambahan informasi dalam memprediksi laba abnormal masa depan dan memiliki relevansi nilai pada semua industri.

Menurut Boubakri (2012), kandungan informasi dari laba dalam hubungannya dengan laba masa depan tergantung pada komponen laba. Ketika laba akuntansi lebih banyak mengandung elemen transitori, maka informasi laba masa depan dan harga saham rendah. Sedangkan, laba akuntansi yang dominan mengandung elemen permanen dalam memberikan informasi laba masa depan dan harga saham tinggi. Komponen laba yang memiliki sifat transitori adalah akrual, sedangkan arus kas mewakili sifat permanen (Persada \&
Martani, 2010).

\section{Arus Kas}

Informasi tentang arus kas dibutuhkan oleh pengguna laporan keuangan untuk menilai kemampuan entitas dalam menghasilkan kas dan setara kas dan kebutuhan entitas dalam menggunakannya. Para pengguna laporan keuangan menggunakan informasi arus kas untuk mengevaluasi kemampuan suatu entitas dalam menghasilkan kas dan setara kas serta mengetahui arus kas yang akan diterimanya.

Pengertian arus kas, dalam PSAK 2 (2009), adalah arus masuk dan arus keluar kas atau setara kas. Kas terdiri atas saldo kas (cash on hand) dan rekening giro (demand deposits). Sedangkan setara kas (cash equivalent) adalah investasi yang bersifat sangat likuid, berjangka pendek, dan yang dengan cepat dapat dijadikan kas dalam jumlah yang dapat ditentukan dan memiliki risiko perubahan nilai yang tidak signifikan.

Informasi mengenai arus kas yang lebih rinci dilaporkan pada laporan arus kas. Laporan arus kas melaporkan arus kas masuk, arus kas keluar, dan perubahan kenaikan dan penurunan kas dari aktivitas operasi, investasi, dan pendanaan selama periode tertentu (Kieso, Weygandt \& Kimmel, 2013).

Akrual

Penman (2010) menyatakan bahwa perbedaan antara laba (earnings) dan arus kas operasi (cash flow from operations) adalah akrual. Akrual merupakan ukuran dari item-item non-kas. Pencatatan itemitem non-kas yang berdasarkan dasar akrual (accrual basis) telah disyaratkan oleh standar akuntansi keuangan dalam proses penyusunan laporan keuangan, kecuali laporan arus kas (PSAK No. 2, 2009). Ketika dasar akrual digunakan, entitas telah memenuhi definisi dan kriteria pengukuran untuk unsur-unsur laporan keuangan, yaitu aset, liabilitas, ekuitas, pendapatan, dan beban.

Penerapan dasar akrual pada proses pelaporan keuangan membuat laporan keuangan tidak hanya memberikan 
informasi mengenai transaksi masa lalu yang melibatkan penerimaan dan pembayaran kas, tetapi juga kewajiban pembayaran kas dimasa depan dan penerimaan kas dimasa depan yang dipresentasikan oleh sumber daya lainnya.

Menurut Suwardjono (2014), dasar akrual (accrual basis) adalah dasar dalam pengakuan pendapatan dan biaya yang menyatakan bahwa pendapatan diakui pada saat hak kesatuan usaha timbul lantaran dalam penyerahan barang atau jasa kepihak luar dan biaya diakui saat kewajiban timbul lantaran penggunaan sumber ekonomik yang melekat pada barang dan jasa yang diserahkan tersebut. Akibat dari penerapan dasar ini, akuntansi mengakui pos-pos akrual (accrued) dan tangguhan (deffered). Pos akrual berisi item -item yang telah menerima kas dari pihak luar atau mengeluarkan kas kepada pihak luar tetapi transaksi tersebut belum dilaksanakan sepenuhnya. Sedangkan pos tangguhan berisi item-item yang telah mengakui transaksi tersebut tetapi belum menerima kas dari pihak luar atau membayar kas kepada pihak luar.

Penghimpunan dan penangguhan (deffering) adalah tahap-tahap yang sangat erat hubungannya dengan proses penandingan (matching). Prinsip penandingan (matching principle) menyatakan bahwa beban harus dicatat pada periode yang sama dengan pendapatan yang telah diakui oleh entitas (Penman, 2010).

Menurut Healey (1985) dalam Putri (2015), ada dua komponen dalam konsep model akrual, yaitu discretionary dan nondiscretionary. Komponen discretionary accruals merupakan komponen akrual yang dapat direkayasa oleh manajer karena manajer memiliki kemampuan untuk mengontrolnya dalam jangka pendek. Sedangkan, komponen non-discretionary accruals tidak dapat direkayasa oleh manajemen karena faktor-faktor luar yang menentukannya, seperti kondisi ekonomi, permintaan pada penjualan dan faktorfaktor lain yang tidak dapat dikontrol oleh manajemen perusahaan.

Penerapan konsep akrual dalam akuntansi dapat mempengaruhi kualitas laba. Apabila perusahaan semakin banyak menerapkan konsep akrual dalam laporan keuangannya, maka semakin banyak gangguan persepsi dalam laba akuntansi sehingga mengurangi kualitas laba.

\section{Pengaruh Perbedaan Laba Akuntansi dan Laba Fiskal terhadap Persistensi Laba}

Dasar berpikir hubungan antara perbedaan laba akuntansi dan laba fiskal dengan persistensi laba adalah manajemen laba (perekayasaan laba). Standar akuntansi memberikan kelonggaran kepada manajemen dalam memilih metode akuntansi, sehingga memberikan peluang bagi manajemen untuk melakukan manajemen laba. Manajemen laba tidak dipandang buruk sepanjang dilakukan dengan tidak melanggar standar akuntansi yang berlaku. Sedangkan peraturan perpajakan membatasi metode akuntansi yang digunakan dalam menghitung laba fiskal. Manajemen laba dapat menyebabkan terjadinya perbedaan laba akuntansi dan laba fiskal. Beberapa penelitian terdahulu menyimpulkan bahwa manajemen laba dapat mempengaruhi kualitas laba yang dihasilkan.

Blaylock et al. (2012) dalam penelitiannya memperoleh bukti bahwa large positive temporary book-tax differences yang timbul dari manajemen laba menunjukkan persistensi laba yang rendah. Hasil penelitian McGuire, Neuman dan Omer (2011) menunjukkan bahwa perusahaan dengan strategi pajak yang lebih berkelanjutan menunjukkan laba sebelum pajak, arus kas dan akrual yang lebih persisten.

Hanlon (2005) dalam Tang dan Firth (2012) menemukan bahwa perusahaan yang memiliki beda temporer perbedaan laba akuntansi dan laba fiskal yang besar menunjukkan persistensi laba dan persistensi akrual yang rendah. Penelitian serupa yang dilakukan Wijayanti (2006) dengan sampel perusahaan manufaktur di Indonesia, menghasilkan bukti empiris bahwa perusahaan dengan large (negative) positive book-tax differences mempunyai persistensi laba lebih rendah yang disebabkan oleh komponen akrualnya daripada perusahaan dengan small book- 
tax differences. Serupa dengan hasil penelitian Adiati dan Rahmawati (2015), bahwa perusahaan dengan large positive/ negative book-tax differences mempunyai persistensi laba yang lebih rendah daripada perusahaan dengan small positive/negative book-tax differences.

Tang dan Firth (2012) mendapatkan bukti empiris bahwa perusahaan dengan large positive atau large negatif normal book-tax differences (abnormal book-tax difference) menunjukkan persistensi laba lebih rendah dengan perusahaan yang memiliki small normal book-tax differences (abnormal book-tax differences). Serupa dengan hasil penelitian Suwandika dan Astika (2013), bahwa large positif book-tax difference menunjukkan persistensi laba yang semakin rendah, sedangkan large negatif book-tax difference tidak menunjukkan persistensi laba yang semakin rendah. Berdasarkan uraian tersebut maka dapat dikembangkan hipotesis sebagai berikut:

H1a : Semakin besar perbedaan laba akuntansi dan laba fiskal yang bernilai positif (large positive booktax difference) maka semakin rendah persistensi laba.

H1b : Semakin besar perbedaan laba akuntansi dan laba fiskal yang bernilai negatif (large negative book -tax difference) maka semakin rendah persistensi laba.

\section{Pengaruh Komponen Laba terhadap Persistensi Laba}

Persistensi laba ditentukan oleh komponen akrual dan aliran kas yang terkandung dalam laba saat ini (Penman, 2001 dalam Fanani, 2010). Hasil penelitian Ahn dan Kwon (2010) menunjukkan bahwa komponen akrual dan arus kas saat ini berhubungan positif dengan kinerja laba masa depan. Boubakri (2012) mengungkapkan bahwa kedua komponen laba saat ini memiliki karakteristik yang berbeda dan konsekuensi yang berbeda pada prediksi laba masa depan. Menurut Persada dan Martani (2010), komponen akrual mewakili sifat transitori, sedangkan komponen arus kas mewakili sifat permanen. Laba yang memiliki sifat permanen lebih persistensi daripada laba yang bersifat transitori.
Menurut Fanani (2010), data arus kas merupakan indikator keuangan yang lebih baik dibandingkan dengan akuntansi karena arus kas relatif lebih sulit untuk dimanipulasi. Manipulasi akuntansi biasanya dilakukan melalui penggunaan metode akuntansi yang berbeda untuk transaksi yang sama dengan tujuan untuk menampilkan laba yang diinginkan. Hasil penelitian Sloan (1996) dalam Ahn dan Kwon (2010), menunjukkan bahwa komponen arus kas lebih persisten daripada komponen akrual.

Persistensi laba akan meningkat jika komponen arus kas semakin meningkat. Oleh karena itu, arus kas operasi disebut sebagai proksi kualitas laba, dimana kualitas laba akan semakin baik seiring semakin tingginya arus kas operasi terhadap laba (Dewi \& Putri, 2015). Berdasarkan uraian tersebut maka dirumuskan hipotesis sebagai berikut:

$\mathrm{H} 2 \mathrm{a}$ : Semakin besar arus kas operasi maka semakin tinggi persistensi laba.

Menurut Wijayanti (2006), beberapa analis keuangan menyatakan bahwa komponen akrual kurang persisten daripada aliran kas, sehingga rasio komponen akrual dalam laba seharusnya diminimalisir agar laba perusahaan memiliki persistensi yang tinggi. Boubakri (2012) memperoleh bukti empiris bahwa koefisien komponen akrual dari laba saat ini dan koefisien non-current operating accruals lebih rendah dibandingkan dengan koefisien persistensi komponen arus kas saat ini.

Schick (2007) dalam Dewi dan Putri (2015) menjelaskan bahwa jika unsur akrual tinggi maka ketepatan prediksi terhadap laba masa depan menjadi rendah, dan jika unsur akrual dalam laba rendah maka laba yang dilaporkan saat ini lebih tepat digunakan untuk memprediksi laba masa depan. Fanani (2010) dalam penelitiannya membuktikan bahwa besarnya akrual yang dimiliki perusahaan berpengaruh negatif dengan persistensi laba. Karena besar kecilnya komponen akrual dalam perusahaan akan meyebabkan gangguan-gangguan tertentu yang menyebabkan berkurangnya tingkat 
persistensi laba perusahaan. Berdasarkan uraian tersebut maka dirumuskan hipotesis sebagai berikut:

$\mathrm{H} 2 \mathrm{~b}$ : Semakin besar akrual maka semakin rendah persistensi laba.

\section{METODE PENELITIAN}

Penelitian ini menguji hubungan perbedaan laba akuntansi dan laba fiskal dan komponen laba terhadap persistensi laba. Variabel independen dalam penelitian ini ada dua, yaitu perbedaan laba akuntansi dan laba fiskal dan komponen laba, yang terdiri dari arus kas dan akrual. Sedangkan variabel dependen penelitian ini adalah persistensi laba yang diukur dari laba akuntansi sebelum pajak. Data yang digunakan dalam penelitian ini adalah data kuantitatif yang diambil dari perusahaanperusahaan manufaktur yang telah go public.

\section{Populasi dan Sampel}

Penulis memilih perusahaan manufaktur yang telah terdaftar pada Bursa Efek Indonesia sebagai populasi dalam penelitian ini. Sampel pada penelitian ini adalah perusahaan manufaktur dari periode tahun 2011 sampai tahun 2013. Sektor manufaktur dipilih karena dampak dari perbedaan laba akuntansi dan laba fiskal lebih teramati dan memiliki karakteristik yang sama untuk bentuk pelaporan keuangannya. Penulis menggunakan teknik purposive sampling dalam menentukan sampel yang akan digunakan. Berikut kriteria perusahaan yang dijadikan sampel dalam penelitian ini, diantaranya:

1. Perusahaan manufaktur yang telah terdaftar di Bursa Efek Indonesia sejak 1 Januari 2011. Berdasarkan kriteria ini terdapat 408 (firm-years) observasi.

2. Menerbitkan laporan keuangan yang diaudit secara konsisten dan lengkap dengan periode pelaporan tahunan yang berakhir pada tanggal 31 Desember, dari tahun 2011 sampai dengan tahun 2014. Berdasarkan kriteria ini diperoleh 408 $12=396$ observasi.

3. Perusahaan menyajikan laporan keuangan dalam mata uang rupiah. Berdasarkan kriteria ini diperoleh 396 $87=309$ observasi.
4. Semua data yang dibutuhkan dalam penelitian ini tersedia dengan lengkap. Berdasarkan kriteria ini diperoleh 309 $15=294$ observasi.

\section{Metode Analisis Data}

Analisis regresi linear berganda (multiple linear regression) dipilih untuk menguji hipotesis penelitian ini, karena penelitian ini menguji hubungan antara variabelvariabel independen dengan variabel dependen. Regresi linear berganda pada penelitian ini, dirumuskan dalam persamaan 1:

$$
\begin{aligned}
\text { PTBI }_{t+1}= & \alpha+\beta_{1} \text { LPBTD }_{t}+\beta_{2} \text { LNBTD }_{t}+\beta_{3} \text { CFO }_{t}+ \\
& \beta_{4} \text { Akrual }_{t}+\varepsilon \ldots \ldots \ldots \ldots \ldots \ldots \ldots \ldots . .(1)
\end{aligned}
$$

PTBI $_{t+1}$ adalah laba akuntansi sebelum pajak tahun depan. $\alpha$ adalah konstanta LPBTD $_{t}$ adalah large positive book-tax differences tahun $\mathrm{t}$. $\mathrm{LNBTD}_{\mathrm{t}}$ adalah large negative book-tax differences tahun t. CFO adalah arus kas operasi tahun t. Akrual adalah akrual tahun t, dan $\varepsilon$ adalah erorr.

\section{Pengukuran Variabel \\ Persistensi Laba}

Variabel dependen dalam penelitian ini adalah persistensi laba. Sesuai dengan Suwandika dan Astika (2013), proksi yang digunakan adalah laba akuntansi sebelum pajak tahun depan $\left(\mathrm{PTBI}_{\mathrm{t}+1}\right)$ dan diukur dengan cara sebagai berikut:

$$
\text { PTBI }_{t+1}=\frac{\text { Laba akuntansi sebelum pajak tahun depan }}{\text { rata-rata total aset }}
$$

\section{Perbedaan Laba Akuntansi dan Laba Fiskal}

Variabel independen pertama dalam penelitian ini adalah perbedaan laba akuntansi dan laba fiskal yang dibagi menjadi dua, yaitu large negative dan large positive. Variabel independen ini diukur dengan variabel dummy, sesuai dengan penelitian Hanlon (2003) dan Suwandika dan Astika (2013), sebagai berikut:

1. Large Positive Book-Tax Difference (LPBTD) yang diperoleh dengan cara mengurutkan perbedaan temporer diwakili oleh akun beban pajak tangguhan per tahun, kemudian seperlima urutan tertinggi dari sampel 
mewakili kelompok LPBTD diberi kode 1 , dan yang lainnya diberi kode 0 .

2. Large Negative Book-Tax Difference (LNBTD) yang diperoleh dengan cara mengurutkan perbedaan temporer diwakili oleh akun manfaat pajak tangguhan per tahun, kemudian seperlima urutan terendah dari sampel mewakili kelompok LNBTD diberi kode 1 , dan yang lainnya diberi kode 0 .

\section{Komponen Laba}

Komponen laba yang terdiri dari arus kas dan akrual. Data arus kas merupakan data arus kas operasi yang diambil langsung dari laporan arus kas, mengacu pada penelitian Dewi dan Putri (2015). Komponen laba kedua, yaitu akrual diukur sesuai dengan penelitian Persada dan Martani (2010) dalam rumus 1.

$$
\text { Akrual }_{\mathrm{t}}=\mathrm{PTBI}_{\mathrm{t}}-\mathrm{CFO}_{\mathrm{t}}
$$

Akrual adalah komponen akrual tahun t. PTBI adalah laba akuntansi sebelum pajak tahun $\mathrm{t}$ dan $\mathrm{CFO}_{\mathrm{t}}$ adalah arus kas operasi tahun $\mathrm{t}$.

\section{ANALISIS DAN PEMBAHASAN}

Berdasarkan hasil uji asumsi klasik dapat dibuktikan bahwa persamaan 1 penelitian ini layak untuk diuji. Berdasarkan Tabel 1 nilai Adjusted $R$ Square sebesar 0,168 atau $16,4 \%$, sehingga dapat disimpulkan bahwa variabel-variabel independennya mampu menjelaskan variabel dependennya sebesar $16,4 \%$ dan sisanya $83,6 \%(100 \%-16,4 \%)$ dijelaskan oleh variabel lain di luar persa-

Tabel 1

Hasil Uji Koefisien Determinasi $\left(\mathrm{R}^{2}\right)$

\begin{tabular}{rrrrr}
\hline $\begin{array}{c}\text { Per- } \\
\text { samaa } \\
\mathbf{n}\end{array}$ & $\mathbf{R}$ & $\begin{array}{c}\mathbf{R} \\
\text { Square }\end{array}$ & $\begin{array}{c}\text { Adj. } \mathbf{R} \\
\text { Square }\end{array}$ & $\begin{array}{l}\text { Std. Error of } \\
\text { the Estimate }\end{array}$ \\
\hline 1 & $0,425^{\mathrm{a}}$ & 0,181 & 0,168 & 0,08856 \\
\hline
\end{tabular}

Tabel 2

Hasil Uji Statistik F

\begin{tabular}{ccccccc}
\hline $\begin{array}{c}\text { Per- } \\
\text { sama } \\
\text { an }\end{array}$ & $\begin{array}{c}\text { Sum of } \\
\text { Square } \\
\text { S }\end{array}$ & Df & $\begin{array}{c}\text { Mean } \\
\text { Squar } \\
\text { e }\end{array}$ & F & Sig. \\
\hline 1 & $\begin{array}{l}\text { Regres- } \\
\text { sion }\end{array}$ & 0,451 & 4 & 0,113 & 14,361 & $0,000^{2}$ \\
& Residual & 2,040 & 260 & 0,008 & & \\
& Total & 2,491 & 264 & & & \\
&
\end{tabular}

maan 1 .

Berdasarkan Tabel 2 tampak nilai $\mathrm{F}$ hasil pengujian sebesar 14,361 dengan signifikansi 0,000. Probabilitasnya sebesar 0,000 yang lebih kecil dari tingkat signifikansi 0,05 , berarti dapat disimpulkan bahwa semua variabel independen secara bersama-sama memepengaruhi variabel dependen dan rumus 1 layak digunakan.

Hasil pengujian statistik secara parsial menunjukkan bahwa penelitian ini mendukung H1a, dapat dilihat dari nilai signifikansi pada Tabel 3 yang lebih kecil dari tingkat signifikansi 0,05, yaitu sebesar 0,006 . Artinya, perbedaan laba akuntansi dan laba fiskal bernilai positif (LPBTD) berpengaruh signifikan terhadap persistensi laba atau dengan kata lain semakin besar perbedaan laba akuntansi dan laba fiskal yang bernilai positif (large positive book-tax difference) maka menunjukkan persistensi laba semakin rendah.

Hasil penelitian ini mendukung penelitian sebelumnya yang menemukan perbedaan laba akuntansi dan laba fiskal bernilai positif (LPBTD) berpengaruh positif dan signifikan terhadap persistensi laba, seperti Hanlon (2003), Wijayanti (2006), Blaylock et al. (2012), Tang dan Firth (2012), Suwandika dan Astika (2015), dan Adiati dan Rahmawati (2015). Berdasarkan hasil pengujian hipotesis ini dapat disimpulkan bahwa perbedaan laba akuntansi dan laba fiskal bernilai positif (large positive book-tax difference) dapat menunjukkan adanya pengaruh manajemen dalam menentukan besarnya laba akuntansi dengan memanfaatkan

Tabel 3

Hasil Uji Statistik t

\begin{tabular}{|c|c|c|c|c|c|c|}
\hline \multirow[b]{2}{*}{$\begin{array}{l}\text { Per- } \\
\text { sama } \\
\text { an }\end{array}$} & & \multirow[t]{2}{*}{$\begin{array}{l}\text { Expect } \\
\text { ed } \\
\text { Sign }\end{array}$} & \multicolumn{2}{|c|}{$\begin{array}{l}\text { Unstandardize } \\
\text { d Coefficients }\end{array}$} & \multirow[b]{2}{*}{$\mathrm{T}$} & \multirow[b]{2}{*}{ Sig. } \\
\hline & & & B & $\begin{array}{l}\text { Std. } \\
\text { Error }\end{array}$ & & \\
\hline \multirow[t]{5}{*}{1} & $\begin{array}{l}\text { (Consta } \\
\text { nt) }\end{array}$ & & 0,07 & 0,007 & 10,274 & 0,000 \\
\hline & LPBTD & H1a- & $-0,04$ & l 0,015 & $-2,784$ & 0,006 \\
\hline & LNBTD & H1b- & $-0,01$ & 20,017 & $-0,698$ & 0,486 \\
\hline & CFO & $\mathrm{H} 2 \mathrm{a}+$ & $2,224 \mathrm{E}-$ & 80,000 & 3,983 & 0.000 \\
\hline & $\begin{array}{l}\text { AKRUA } \\
\text { L }\end{array}$ & $\mathrm{H} 2 \mathrm{~b}-$ & $6,043 \mathrm{E}-$ & 80,000 & 4,980 & 0,000 \\
\hline
\end{tabular}


peluang yang ada dalam standar akuntansi.

Hasil pengujian hipotesis ini menunjukkan bahwa penelitian ini tidak mendukung $\mathrm{H} 1 \mathrm{~b}$, dapat dilihat dari nilai signifikansi pada Tabel 3 yang lebih besar dari tingkat signifikansi 0,05, yaitu sebesar 0,486. Artinya, perbedaan laba akuntansi dan laba fiskal bernilai negatif (LNBTD) tidak berpengaruh signifikan terhadap persistensi laba atau dengan kata lain semakin besar perbedaan laba kuntansi dan laba fiskal yang bernilai negatif (large negative book-tax difference) tidak menunjukkan persistensi laba rendah pada tingkat 95\%.

Hasil penelitian ini tidak dapat membuktikan hasil penelitian Hanlon (2003), Tang dan Firth (2012), dan Adiati dan Rahmawati (2015) yang menemukan bahwa perbedaan laba akuntansi dan laba fiskal bernilai negatif berpengaruh negatif dan signifikan terhadap persistensi laba. Namun, penelitian ini mendukung penelitian Wijayanti (2006), Suwandika dan Astika (2013), dan Prihanto (2014) yang juga menemukan bahwa perbedaan laba akuntansi dan laba fiskal bernilai negatif tidak berpengaruh signifikan terhadap kualitas laba.

Hasil pengujian hipotesis ini menunjukkan bahwa penelitian ini mendukung $\mathrm{H} 2 \mathrm{a}$, dapat dilihat dari nilai signifikansi pada Tabel 3 yang lebih kecil dari tingkat signifikansi 0,05, yaitu sebesar 0,000. Artinya, arus kas operasi (CFO) berpengaruh signifikan terhadap persistensi laba atau dengan kata lain semakin besar arus kas operasi maka menunjukkan persistensi laba semakin tinggi.

Hasil penelitian ini membuktikan penelitian Ahn dan Kwon (2010), dan Dewi dan Putri (2015) yang menemukan arus kas operasi berpengaruh positif dan signifikan terhadap persistensi laba. Selain itu, penelitian ini juga mendukung penelitian Wulandari (2005) dan Persada dan Martani (2010) yang menemukan bahwa arus kas operasi memiliki pengaruh positif dan signifikan terhadap laba masa depan. Hal ini berarti semakin besar arus kas operasi perusahaan maka kualitas laba akan meningkat.
Berdasarkan Tabel 3 hasil uji statistik $\mathrm{t}$ untuk variabel akrual menunjukkan signifikan karena nilai sigfikan sebesar 0,000 yang lebih rendah dari tingkat signifikansi 0,005. Koefisien regresi variabel Akrual sebesar 6,043 dengan tanda positif menunjukkan bahwa penelitian secara empiris memperoleh bukti bahwa akrual berhubungan positif dan signifikan dengan persistensi laba, tetapi tidak mendukung H2b. Penelitian ini tidak dapat membuktikan penelitian Sloan (1996) dalam Fanani (2010) dan Fanani (2010) yang menemukan bahwa akrual berhubungan negatif dan signifikan dengan persistensi laba. Hal ini disesuaikan oleh fakta bahwa tingkat akrual merupakan proxy untuk manfaat akrual (benefit of accruals) dan untuk korelasi biaya dari proses akrual (cost of accrual process). Hal ini berarti sistem akrual yang efisien, ketika akrual dicatat sampai marginal manfaat akrual (mengatasi masalah waktu arus kas) sama dengan marginal biaya akrual (menimbulkan kesalahan estimasi). Mengoptimalkan tingkat akrual akan menghasilkan tingginya akrual pada perusahaan. Sehingga perusahaan dengan tingginya akrual akan mempunyai manfaat yang besar dari akrual tetapi juga memiliki biaya dan rendahnya kualitas laba (Dechow \& Dichev, 2001).

\section{SIMPULAN}

Perbedaan laba akuntansi dengan laba fiskal dalam penelitian ini dibagi menjadi dua, yaitu perbedaan laba akuntansi dengan laba fiskal bernilai positif (LPBTD) dan perbedaan laba akuntansi bernilai negatif (LNBTD). Hasil penelitian menunjukkan hanya perbedaan laba akuntansi dengan laba fiskal bernilai positif yang berpengaruh signifikan terhadap persistensi laba. Sedangkan perbedaan laba akuntansi dengan laba fiskal bernilai negatif (LNBTD) tidak berpengaruh signifikan terhadap persistensi laba. Hal ini disebabkan tidak semua manfaat pajak tangguhan dapat direalisasikan dimasa depan. Sedangkan beban pajak tangguhan yang terealisasi dimasa depan dapat mengurangi laba akuntansi, sehingga perbedaan laba 
akuntansi dan laba fiskal bernilai positif berpengaruh terhadap persistensi laba.

Komponen laba yang terdiri dari arus kas dan akrual memiliki pengaruh terhadap persistensi laba. Komponen arus kas yang diukur dari arus kas operasi mempunyai pengaruh yang signifikan dan positif terhadap persistensi laba. Hal ini disebabkan komponen arus kas yang bersifat permanen dan mempunyai ketepatan waktu. Sedangkan komponen akrual berhubungan positif dan signifikan terhadap persistensi laba, tetapi tidak dapat mendukung hipotesis.

\section{KETERBATASAN DAN SARAN}

\section{Keterbatasan}

Penelitian ini memiliki beberapa keterbatasan yang perlu diperhatikan dalam mengintepretasikan hasil analisis pada penelitian ini. Keterbatasan pertama penelitian ini menggunakan periode pengamatan yang relatif pendek, yaitu tiga tahun dibandingkan dengan literatur acuan yang mengambil periode waktu selama lima tahun. Oleh karena itu, penelitian ini kurang mampu menjelaskan pengaruh dari perbedaan laba akuntansi dengan laba fiskal dan komponen laba terhdap persistensi laba. Keterbatasan kedua adalah penelitian ini memilih sektor manufaktur berdasarkan proses produksi secara umum, tetapi belum memfokuskan pada sub sektor manufaktur tertentu berdasarkan karaktertistik proses produksi masing-masing sub sektor tersebut.

\section{Saran}

Saran untuk penelitian adalah untuk penelitian selanjutnya diharapkan dapat menggunakan periode pengamatan jangka panjang, yaitu lebih dari tiga tahun, sehingga mungkin dapat memberikan hasil yang lebih baik dalam penelitian. Serta, diharapkan dapat memfokuskan pada sub sektor manufaktur tertentu, misalnya sektor consumer good indutry, miscellanieous industry atau basic industry and chemicals, sehingga akan memberikan hasil penelitian yang lebih baik.

\section{DAFTAR PUSTAKA}

Adiati, A.K., \& Rahmawati. (2015).
Manajemen laba, large book-tax difference, dan persistensi laba. Paper dipresentasikan pada acara Simposium Nasional Akuntansi XVIII, Medan.

Ahn, H.B., \& Kwon, G.J. (2010). Earnings persistence and market reaction: Evidance from Korea. International Journal of Business and Management, 5(10), 10-19.

Anggarsari, D.S. (2009). Persistensi laba, akrual, aliran kas, dan book-tax differences (Skripsi). Universitas Sebelas Maret, Fakultas Ekonomi dan Bisnis, Surakarta.

Anggono, A., \& Baridwan, Z. (2003). Pengaruh kebijakan pembagian dividen, kualitas akrual, dan ukuran perusahaan pada relevansi nilai dividen, nilai buku, dan laba. Paper dipresentasikan pada acara Simposium Nasional Akuntansi VI, Surabaya.

Ayers, B.C., Laplante, S.K., \& McGuire, S. T. (2008). Credit ratings and taxes: the effect of book/tax differences on ratings changes. Working Paper University of Georgia.

Blaylock, B., Shevlin, T., \& Wilson, R.J. (2012). Tax avoidance, large positive temporary book-tax differences, and earnings persistence. The Accounting Review, 87(1), 91-120.

Boubakri, F. (2012). The relationship between accrual quality, earnings persistence and accruals anomaly in the Canadian context. International Journal of Economics and Finance, 4 (6), 51-62.

Dechow, P.M., \& Dichev, I.D. (2001). The quality of accruals and earnings: The role of accrual estimation errors. Working Paper, University of Michigan Business School.

Dechow, P., Ge, W., \& Schrand, C. (2010). Understanding earning quality: A review of the proxies, their determinants and their consequences. Working Paper, www.ssrn.com.

Dewi, N.P.L., \& Putri, I.G.A.M.A.D. (2015). Pengaruh book-tax difference, arus kas operasi, arus kas akrual, dan ukuran perusahaan pada persistensi laba. E-Jurnal Akuntansi Universitas Udayana, 10(1), 244-260.

Fanani, Z. (2010). Analisis faktor-faktor 
penentu persistensi laba. Jurnal Akuntansi dan Keuangan Indonesia, 7 (1), 109-123.

Hanlon, M.L. (2003). The persistence and pricing of earnings, accruals and cash flows when firm have large book-tav difference. Working Paper (Dissertation), University of Washington.

Huang, D.F., \& Wang, C.L. (2013). Book-tax differences and earning quality for the banking industry: Evidence from Taiwan. Pacific Accounting Review, 25 (2), 145-164.

Ikatan Akuntan Indonesia. (2009). Pernyataan standar akuntansi keuangan. Jakarta: Salemba Empat.

Jackson, M. (2009). Book tax differences and earnings growth. Working Paper (Dissertation), University of Oregon.

Kieso, D.E., Weygandt, J.J., \& Kimmel, P.D. (2013). Financial accounting IFRS edition (2nd ed.). United States of America: John Wiley \& Sons.

Kraft, A. (2015). Management earnigs forecasts and book-tax differences. International Journal of Economics and Finance, 7(3), 1-24.

Martani, D., Fitriasari, D., \& Yulianti. (2010). Influence of book tax gap towards earnings persistence and firm value for the period of 1999 - 2007. The Third Accounting \& The Second Doctoral Colloquium, Bali.

McGuire, S.T., Neuman, S.S., \& Omer, T.C. (2011). Sustainable tax strategies and earnings persistence. Working Paper, Texas A\&M University.

Penman, S.H. (2010). Financial statement analysis and security valuation international edition. Singapore: Mc Graw Hill.

Penman, S.H., \& Zhang, X.J. (2002). Accounting conservatism, the quality of earning and stock returns. Working Paper, www.ssrn.com.

Persada, A.E., \& Martani, D. (2010). Analisis faktor yang mempengaruhi book tax gap dan pengaruhnya terhadap persistensi laba. Jurnal Akuntansi dan Keuangan Indonesia, 7(2), 205-221.

Prihanto, H.B. (2014). Analisis pengaruh book tax differences terhadap kualitas laba (Studi pada perusahaan perbankan yang terdaftar di bursa efek Indonesia) (Skripsi). Universitas Sebelas Maret, Fakultas Ekonomi dan
Bisnis, Surakarta.

Putri, D.P. (2015). Pengaruh struktur dewan komisaris terhadap manajemen laba pada industri perbankan di Indonesia (Skripsi). Universitas Sebelas Maret, Fakultas Ekonomi dan Bisnis, Surakarta.

Razshinta, H. (2015). Pengaruh mekanisme corporate governance terhadap kualitas laba pada perusahaan perbankan yang terdaftar di bursa efek Indonesia tahun 2011-2013 (Skripsi). Universitas Sebelas Maret, Fakultas Ekonomi dan Bisnis, Surakarta.

Sekaran, U., \& Bougie, R. (2013). Research methods for business, a skill - building approach (6th ed.). United Kingdom: John Wiley \& Sons Ltd.

Suandy, E. (2011). Perencanaan pajak (Edisi 5). Jakarta: Salemba Empat.

Sujarweni, V.W. (2015). Metodologi penelitian bisnis \& ekonomi. Yogyakarta: Pustaka Baru Press.

Sumarsan, T. (2013). Tax review dan strategi perencanaan pajak. Jakarta: Indeks.

Supriyono, F. (2013). Pengaruh book tax differences terhadap persistensi laba (Studi empiris pada perusahaan manufaktur yang terdaftar di bursa efek Indonesia tahun 2008-2011) (Skripsi). Universitas Sebelas Maret, Fakultas Ekonomi dan Bisnis, Surakarta

Suwandika, I.M.A., \& Astika, I.B.P. (2013). Pengaruh perbedaan laba akuntansi, laba fiskal, tingkat hutang pada persistensi laba. E-Jurnal Akuntansi Universitas Udayana, 5(1), 196-214.

Suwardjono. (2014). Teori akuntansi perekayasaan dan pelaporan Keuangan (Edisi Ketiga). Yogyakarta: Penerbit BPFE.

Tang, T.Y.H., \& Firth, M. (2011). Can booktax differences capture earning management and tax management? Empirical evidence from China. The International Journal of Accounting, 46, 175-204.

Tang, T.Y.H., \& Firth, M. (2012). Earnings persistence and stock market reactions to the different information in book-tax differences: Evidence from China. The International Journal of Accounting, 47, 369-397.

Waluyo. (2014). Akuntansi pajak (Edisi 5). Jakarta: Salemba Empat.

Wijayanti, H.T. (2006). Analisis pengaruh perbedaan antara laba akuntansi dan laba fiskal terhadap persistensi laba, akrual, dan arus kas. Paper dipresen- 
tasikan pada acara Simposium

Nasional Akuntansi IX, Padang.

Wiryandari, S.A., \& Yulianti. (2009). Hubungan perbedaan laba akuntansi \& laba pajak dengan perilaku manajemen laba dan persistensi laba. Paper dipresentasikan pada acara Sim- posium Nasional Akuntansi XII, Palembang.

Wulandari, R.M. (2005). Analisis arus kas dalam memprediksi laba perusahaan (Tesis). Universitas Sebelas Maret, Fakultas Ekonomi dan Bisnis, Surakarta. 